\title{
Meninjau Kembali Sejarah Banten \\ Studi Kasus Pemerintahan Sultan Ageng Tirtayasa dan Implementasi Kepemimpinannya
}

\section{Reviewing the History of Banten \\ Case Study of Sultan Ageng Tirtayasa's Government and Implementation of His Leadership}

\section{Usman Manor}

Kementerian Koordinator Bidang Pembangunan Manusia dan Kebudayaan

\section{Penulis Korespondensi}

Usman Manor

manorusman@gmail.com +6281314026616

\begin{abstract}
Abstrak
Pada tahun 2020, penduduk miskin di Provinsi Banten mencapai 857.640 orang atau mengalami kenaikan dibandingkan dengan tahun sebelumnya sebesar 654.460 orang. Padahal Banten memiliki potensi pertanian, peternakan, perikanan, pertambangan, energi, dan pariwisata yang sebenarnya mampu mereduksi kemiskinan dan mengoptimalkan kesejahteraan rakyat. Pada masa lalu, Banten merupakan pelabuhan besar yang mengalami masa kejayaan pada masa pemerintahan Sultan Ageng Tirtayasa tahun 1651 sampai dengan tahun 1682. Implementasi strategi yang digunakan oleh Sultan Ageng Tirtayasa dalam membawa kejayaan Banten perlu dikaji sehingga diperlukan peninjauan kembali terhadap sejarah Banten pada masa Sultan Ageng Tirtayasa. Penulisan jurnal ini bertujuan untuk mengidentifikasi permasalahan yang dialami oleh Banten dengan mengacu pada masa Pemerintahan Sultan Ageng Tirtayasa yang mengimplementasikan strategi Defence Agency. Metode dalam penulisan jurnal ini adalah metode kualitatif yang diperkuat oleh metode sejarah berupa heuristik, kritik, interpretasi, dan historiografi dengan pengumpulan data melalui wawancara dan studi kepustakaan. Temuan dalam penelitian adalah kemampuan Sultan Ageng Tirtayasa dalam memahami konteks, membuat keputusan dengan mempertimbangkan risiko, dan mengeksekusi keputusan dalam keadaan sulit yang disebut sebagai Defence Agency membuat Banten tetap bertahan dalam menghadapi blokade ekonomi VOC. Kesimpulan penulisan jurnal ini adalah Banten berkembang pesat di bawah pimpinan Sultan Ageng Tirtayasa sebagai kerajaan besar dan pelabuhan internasional. Meskipun menghadapi blokade ekonomi oleh VOC dan konflik politik, strategi Defence Agency yang diterapkan oleh Sultan Ageng Tirtayasa nyatanya mampu membuat Banten mengalami masa kejayaan. Implementasi dari Defence Agency yang diterapkan oleh Sultan Ageng Tirtayasa tersebut dapat diterapkan pada masa sekarang guna membangkitkan kembali kejayaan Banten pasca Pandemi Covid-19.
\end{abstract}

\section{Kata Kunci}

Banten; Defence Agency; Sultan Ageng Tirtayasa; VOC

\section{Abstract}

In 2020, the poor population in Banten Province reached 857,640 people or an increase compared to the previous year of 654,460 people. Whereas Banten has the potential for agriculture, animal husbandry, fisheries, mining, energy, and tourism which are actually capable of reducing poverty and optimizing people's welfare. In the past, Banten was a major port that experienced a heyday during the reign of Sultan Ageng Tirtayasa in 1651 to 1682. The implementation of the strategy used by Sultan Ageng Tirtayasa in bringing Banten glory needs to be studied so that a review of the history of Banten during the reign of Sultan Ageng is needed. Tirtayasa. Writing this journal aims to identify the problems experienced by Banten with reference to the reign of Sultan Ageng Tirtayasa who implemented the Defense Agency strategy. The method in writing this journal is a qualitative method which is strengthened by historical methods in the 
ARTIKEL

form of heuristics, criticism, interpretation, and historiography by collecting data through interviews and literature studies. The findings in this study are the ability of Sultan Ageng Tirtayasa to understand the context, make decisions by considering risks, and execute decisions in difficult circumstances known as the Defense Agency, making Banten survive in the face of the VOC economic blockade. The conclusion of writing this journal is that Banten is growing rapidly under the leadership of Sultan Ageng Tirtayasa as a large kingdom and international port. Despite facing an economic blockade by the VOC and political conflicts, the Defense Agency strategy implemented by Sultan Ageng Tirtayasa was actually able to make Banten experience a heyday. The implementation of the Defense Agency implemented by Sultan Ageng Tirtayasa can be applied today in order to revive the glory of Banten after the Covid-19 Pandemic.

\section{Keywords}

Banten; Defence Agency; Sultan Ageng Tirtayasa; VOC 


\section{Pendahuluan}

Banten merupakan suatu wilayah yang secara umum memiliki ketinggian 0 hingga 257,93 meter di atas permukaan laut (Statistik, 2021, hlm. 4). Banten menjadi sebuah Provinsi setelah dilakukan pemekaran atas wilayah Jawa Barat pada tahun 2000 yang dikukuhkan melalui Undang-Undang Nomor 23 Tahun 2000. Mengacu pada laman Kementerian Pendidikan, Kebudayaan, Riset, dan Teknologi, kata Banten berasal dari beberapa istilah, yaitu Katiban Inten (kejatuhan intan) yang merujuk pada asal-usul masyarakat Banten yang pada masa lalu menyembah berhala, kemudian memeluk agama Budha dan Bantahan yang merujuk pada ketidakmauan masyarakat tunduk pada aturan yang dibuat oleh VOC. Selain itu, nama Banten juga dianggap berasal dari nama sungai Cibanten.

Secara administratif berdasarkan Peraturan Menteri Dalam Negeri Nomor 72 Tahun 2019, Provinsi Banten memiliki luas 9.662,92 kilometer persegi yang terdiri dari 4 (empat) Kota, yaitu Kota Tangerang, Cilegon, Serang, dan Tangerang Selatan serta 4 (empat) Kabupaten, yaitu Kabupaten Pandeglang, Lebak, Tangerang, dan Serang. Kabupaten Lebak menjadi wilayah terluas di Provinsi Banten dengan luas wilayah mencapai 2.746,89 kilometer persegi, sementara Kota Tangerang Selatan menjadi wilayah terkecil dengan luas hanya 147,19 kilometer persegi.

Provinsi Banten yang secara geografis berdekatan dengan Ibukota Jakarta memiliki kekayaan budaya dan historis yang ditunjang oleh kondisi geografis dan potensi alam. Sebagai penghasil beras dan lada terbesar di Pulau Jawa pada masa lalu yang berkontribusi besar bagi kejayaan Kerajaan Banten, kini justru Banten mengalami kemunduran. Tercatat pada tahun 2019 penduduk miskin di Provinsi Banten berjumlah 654.460 orang atau 2,60\% dari total penduduk miskin di Indonesia (Statistik, 2020, hlm. 646). Pada tahun 2020, penduduk miskin di Provinsi Banten meningkat signifikan yang ditunjang oleh dampak dari mewabahnya Pandemi Covid-19 sebesar 857.640 orang (Statistik, 2021, hlm. 149-150). Padahal pada tahun 2019, Banten mengalami pertumbuhan ekonomi 5,53\% yang melebihi rata-rata pertumbuhan ekonomi nasional, yakni 5,02\%. Selain itu, pada tahun yang sama Banten membukukan realisasi pendapatan mencapai 11,20 triliun rupiah dengan kontribusi pendapatan terbesar berasal dari Pendapatan Asli Daerah (PAD) sebesar 7,02 triliun rupiah. Akan tetapi, realisasi belanja Pemerintah Daerah mencapai 11,33 triliun rupiah (Statistik, 2020, hlm. 28). Hal ini mencerminkan adanya defisit pendapatan daerah Provinsi Banten pada tahun 2019. Pada tahun berikutnya, pendapatan Provinsi Banten mengalami penurunan menjadi 10,33 triliun rupiah yang ditunjang penurunan PAD menjadi 5,91 triliun rupiah. Penurunan tersebut sejalan dengan realisasi belanja Pemerintah Provinsi Banten yang tidak terserap maksimal dengan hanya mencapai 10,07 triliun (Statistik, 2021, hlm. 44).

Kemiskinan yang dialami penduduk Banten tersebut justru sangat bertolak belakang dengan kondisi kejayaan masa lalu Kerajaan Banten yang dikenal pula sebagai Kesultanan Banten, terutama pada masa Pemerintahan Sultan Ageng Tirtayasa. Pada masa tersebut, Bangsa Eropa sangat tertarik untuk bekerja sama bahkan menguasai Banten yang dianggap potensial.

Pada mulanya orang Eropa datang ke Nusantara dengan tujuan untuk mencari rempah-rempah dan berdagang. Hal ini dilakukan Portugis, negara Eropa pertama yang datang ke Indonesia dengan motif ekonomi, politik, dan agama (Zuhdi, 2012, hlm. 1). Migrasi orang Eropa ke Indonesia juga diperlambat dengan ditetapkannya Konstantinopel sebagai pusat pengiriman uang ke Turki Usmani pada tahun 1453. Akibatnya, kemajuan ilmu pengetahuan dan teknologi seperti transportasi, navigasi, dan komunikasi di Eropa menyebabkan lonjakan. dalam migrasi samudra sampai ke Nusantara.

Hal yang sama terjadi pada Belanda. Kegiatan ekonomi yang dilakukan oleh Belanda pada abad 15 hanya sebatas pada perdagangan garam, anggur, dan tekstil serta mendistribusikan rempah-rempah dari Asia ke pelabuhan Lisabon, sebuah pelabuhan pasca jatuhnya Konstantinopel (Zuhdi, 2012, hlm. 2). Namun, perang antara Spanyol dengan Belanda pada tahun 1568 membuat pelabuhan Lisabon jatuh ke tangan Spanyol pada tahun 1580 sehingga menghambat perdagangan dan distribusi barang yang dilakukan oleh Belanda (Zuhdi, 2012, hlm. 3).

Dengan jatuhnya Lisabon ke tangan Spanyol, maka Belanda berinisiatif untuk mendatangi langsung sumber rempah-rempah. Untuk mewujudkan hal tersebut, 
Belanda mengumpulkan para ahli ilmu bumi, antara lain Plancius dan Mercantor (Zuhdi, 2012, hlm. 3). Pada saat yang sama, terbit buku karya Jan Huygen van Linscoten berjudul Itineratio yang berisi tentang Hindia (Indonesia) berikut kekuasaan Portugis di Hindia (Indonesia) tersebut. Buku ini yang kemudian menginspirasi Cornelius de Houtman dan Pieter de Keyser untuk melakukan pelayaran ke Nusantara. Pada tanggal 2 April 1595, berangkatlah 4 buah kapal dari pangkalan Tessel di Belanda Utara dan sampai di Pelabuhan Banten pada tanggal 23 Juni 1596 (Zuhdi, 2012, hlm. 3).

Kawasan Nusantara memiliki posisi tersendiri dalam percaturan perdagangan dan pelayaran kuno antara AsiaEropa. Posisi yang strategis dan terbuka dalam lalu lintas perdagangan internasional itu telah menyebabkan kawasan Nusantara menjadi incaran dan ajang perebutan bangsa-bangsa Barat. Strategis bermakna letaknya baik dan menguntungkan, sedangkan terbuka berarti Nusantara terbuka oleh jalur hubungan antarpulau dan antarnegara. Dengan memiliki letak posisi silang, kawasan Nusantara menerima dampak positif dan negatif akibat timbulnya hubungan antarnegara yang melewati wilayah ini. Dampak positif dari posisi silang, yakni Nusantara dapat berperan menjadi jembatan lalu lintas perdagangan dan pelayaran internasional. Nusantara pun bias menjadi tempat persinggahan sementara bagi kapal-kapal yang melewatinya. Adapun dampak negatif dari posisi silang, yaitu mudah mendatangkan bahaya dan ancaman dari luar terhadap Nusantara. Selain itu, mudah masuknya budaya luar yang tidak sesuai dengan kepribadian masyarakat Nusantara.

Di Nusantara muncul beberapa pusat perdagangan penting setelah sebelumnya mampu tampil sebagai pemasok barang komoditas bagi bangsa-bangsa asing, terutama rempah-rempah. Aktivitas perdagangan dan pelayaran internasional di Nusantara dapat berjalan dengan baik sebab negeri-negeri pemilik pusat perdagangan di Nusantara dapat mengamankan wilayah perairannya sehingga memberi jaminan keamanan kepada setiap bangsa. Selain itu, penduduk Nusantara termasuk bangsa yang memiliki kepandaian dan keberanian mengarungi samudera luas. Semua itu menyebabkan posisi Nusantara menjadi teramat penting dalam percaturan perdagangan dan pelayaran antara Asia-Eropa.

Perdagangan dan pelayaran menjadi aspek penting dari perjumpaan budaya Eropa khususnya Belanda dengan budaya lokal di Nusantara. Perjumpaan budaya antara Eropa dan budaya lokal terlihat secara jelas dari perkawinan silang antara orang Eropa dan orang pribumi. Perjumpaan budaya ini memunculkan budaya baru bernama Indis yang memiliki karakteristik berupa gaya hidup mewah, arsitektur lokal berpadu dengan arsitektur Eropa, dan munculnya komunitas Katholik Jawa.

Pemilihan Banten sebagai tema dalam penulisan jurnal ini didasari atas kemunduran yang dialami Banten, padahal sejarah Banten menunjukkan potensi alam yang besar dan menjadi salah pelabuhan besar yang pernah ada dalam sejarah maritim di Indonesia. Banten juga menjadi rujukan dalam penulisan sejarah kerajaan di Nusantara. Hal ini merujuk pada karakteristik Banten yang khas, yaitu perpaduan tradisi Jawa dan tradisi Melayu yang menjadikan Banten sebagai penghubung antara kedua tradisi tersebut. Hubungan ini diperkuat dengan adanya kegiatan perdagangan dalam suatu Pelabuhan yang di dalamnya terdapat interaksi manusia yang sangat heterogen (C. Guillot, 2008, hlm. 11). Kepemimpinan Sultan Ageng Tirtayasa yang berupaya untuk menyejahterakan masyarakat Banten kala itu perlu untuk dikemukakan kembali guna menjadikan sebagai pelajaran untuk masa kini dan masa mendatang. Banten tumbuh oleh masyarakat yang mengoptimalkan hasil alam melalui perdagangan yang diatur oleh elite birokrasi dengan landasan hukum Islam dan ditopang oleh kekuatan militer mumpuni pada masa itu. Pada awalnya masyarakat di Banten hanya diklasifikasi menjadi dua kelompok, yaitu penguasa dan masyarakat agrikultur (Michrob, 2011, hlm. 10). Kemudian klasifikasi ini berkembang menjadi Ulama, Elit Birokrasi yang menjadi penguasa, Jawara, dan Rakyat Jelata. Namun demikian, pasca dikuasai oleh VOC hingga kini, Banten seakan tenggelam dalam romantisme masa lalu dan tertinggal dalam hal pembangunan hingga berdampak pada kesejahteraan penduduk jika dibandingkan dengan wilayah lain di Pulau Jawa. Selain itu, dalam pencarian sumber-sumber terkait dengan tema pun tidak terlalu sulit. 
Dengan dilatarbelakangi fakta penurunan tingkat kesejahteraan rakyat dan kurangnya pemahaman konteks sejarah, diperlukan upaya untuk membangkitkan kembali narasi sejarah Banten guna mendorong peningkatan pembangunan kebudayaan yang bermuara pada kesejahteraan penduduk. Fokus permasalahan yang akan dibahas dalam penulisan jurnal ini adalah implementasi strategi Sultan Ageng Tirtayasa dalam menghadapi masa sulit Kerajaan Banten terutama saat blokade ekonomi oleh VOC yang diperparah dengan adanya konflik politik. Dalam menghadapi blokade masa sulit tersebut, Sultan Ageng Tirtayasa menggunakan strategi yang masih relevan digunakan hingga saat ini, yaitu "Defense Agency" pada jurnal A Dynamic Strategy for Uncertain Times (Bryan, 2010). Berdasarkan pokok permasalahan tersebut, rincian permasalahan mendasar, yaitu keadaan Kerajaan Banten dalam kurun waktu 1651 sampai dengan 1682, tekanan pada masa pemerintahan Sultan Ageng Tirtayasa, dan implementasi Defence Agency dalam merespons tekanan berupa blokade ekonomi oleh VOC dan konflik politik.

Secara umum, tujuan dari penulisan jurnal ini adalah meninjau kembali sejarah kejayaan Banten pada masa Sultan Ageng Tirtayasa sekaligus mengidentifikasi implementasi strategi "Defence Agency" yang diterapkan oleh Sultan Ageng Tirtayasa. Secara khusus, tujuan yang hendak dicapai adalah menjelaskan kondisi Banten pada masa lalu, mendeskripsikan masa sulit yang dialami oleh Sultan Ageng Tirtayasa, dan menganalisis implementasi strategi Defence Agency yang masih relevan hingga saat ini.

Dalam penulisan sejarah, periodisasi sebagai aspek temporal dan geografi sebagai aspek spasial merupakan hal yang penting. Untuk itu, periodisasi yang digunakan dalam adalah tahun 1651 sampai dengan 1682 di Banten. Antara tahun 1651 sampai dengan 1682 merupakan kurun waktu Sultan Ageng Tirtayasa berkuasa di Kesultanan Banten dan membawa Pelabuhan Banten pada kemajuan yang pesat Periode ini yang dijadikan acuan oleh penulis dalam mengidentifikasi upaya yang dapat dilakukan guna membangkitkan kembali sejarah Banten. Pada rentang tahun tersebut, Banten sering kali menentang VOC. Sebelum tahun 1651 atau sebelum Sultan Ageng Tirtayasa berkuasa di Banten, VOC dapat menanamkan kekuasaannya dengan selalu turut campur dalam urusan kesultanan Banten baik dibidang politik maupun ekonomi (Poesponegoro \& Susanto, 2010, hlm. 68).

Pada tahun 1682, VOC berhasil mengalahkan Banten setelah berulang kali mendapatkan perlawanan. Bagi VOC, Banten merupakan musuh yang sulit ditaklukkan melebihi Mataram (Zuhdi, 2012, hlm. 24). Tahun tersebut merupakan akhir dari pemerintahan Sultan Ageng Tirtayasa dan awal bagi VOC dalam menanamkan kekuasaannya dan memonopoli perdagangan di Banten. Pasca jatuhnya Banten dalam cengkeraman VOC, Banten mengalami kemunduran dan mengalami ketertinggalan dalam hal pembangunan hingga kini. Banten seakan inferior jika dibandingkan dengan wilayah lainnya di Pulau Jawa.

Selama tiga dekade atau lebih tepatnya 31 tahun masa Pemerintahan Sultan Ageng Tirtayasa, kejayaan Banten sebagai Pelabuhan dan kemampuan Banten dalam mengelola potensi alam mampu berkontribusi pada kesejahteraan masyarakat. Kini 21 tahun pasca Banten berdiri sebagai sebuah Provinsi, kejayaan dan kesejahteraan tersebut belum mampu diulang. Namun mengacu pada kurun waktu pemerintahan Sultan Ageng Tirtayasa yang mencapai 31 tahun, dengan asumsi 21 usia Banten terbuka harapan setidaknya 10 tahun bagi Banten untuk mengejar ketertinggalan dan mengoptimalkan potensi yang dimiliki guna meningkatkan kesejahteraan penduduk serta mengulang kembali kejayaan masa lalu pada tahun 2031.

Jika dikaitkan dengan penelitian terdahulu, penulisan sejarah Banten hanya menjelaskan perkembangan kejayaan masa lalu Kerajaan Banten dan persinggungan dengan kolonial seperti Tinjauan Kritis tentang Sejarah Banten, Banten Dalam Pergumulan Sejarah, Banten Kota Pelabuhan Jalur Sutra, Catatan Masa Lalu Banten, Jan Kompeni; Dalam Perang dan Damai 1602-1799, VOC di Kepulauan Indonesia: Berdagang dan Menjajah, serta Banten Sejarah dan Peradaban Abad X-XVII. Penulisan sejarah Banten didominasi oleh rangkaian peristiwa mulai dari Banten sebelum pengaruh Islam hingga mendapatkan pengaruh kolonialisme dari VOC. Hingga kini, belum ada upaya penulisan sejarah Banten yang dikaitkan dengan upaya dalam membangkitkan kembali narasi kejayaan masa lalu Banten dengan tujuan mengulang kembali keberhasilan tersebut dengan 
indikator meningkatnya kesejahteraan masyarakat dan menurunnya jumlah penduduk miskin.

Penelitian terbaru tentang Banten hanya menjelaskan peluruhan kebudayaan maritim yang ditunjang dengan degradasi sejarah, identitas, dan praktik sosial (Octavian \& Yulianto, 2014). Aspek politik dan sosial turut dibahas dalam perkembangan Banten pada masa Sultan Ageng Tirtayasa (Anggraheni dkk., 2020). Sementara itu, penelitian yang khusus mengkaji perlawanan Kerajaan Banten terhadap dominasi kolonial Belanda tidak membahas secara spesifik potensi, permasalahan berupa konflik elite kerajaan, dan dinamika perlawanan (Ulfah, 2020). Selain itu, tinjauan kembali terhadap Sejarah Banten hanya menyoroti metodologi, substansi, dan sumber sejarah yang digunakan oleh Claude Guillot dalam buku Banten, Sejarah, dan Peradaban Abad XXVII (K. C. Guillot, 2009, hlm. 313). Sejalan dengan penelitian tersebut, penelitian sejarah Banten lainnya juga berupaya mengkaji ulang dan mengkritisi penulisan sejarah Banten dalam Catatan Masa Lalu Banten karya Halwany Michrob yang hanya fokus pada narasi sejarah dan tinggalan bukti arkeologis saja (Fida, 2019, hlm. 16). Seperti halnya Fida, penulisan sejarah Banten oleh Hoesein Djajadiningrat turut dikaji ulang untuk mengungkap perspektif lain, meskipun tidak dijelaskan secara rinci perspektif tersebut (Nuralam, 2019).

Penelitian lain yang berkaitan dengan sejarah masyarakat Banten hanya menjelaskan kompleksitas masyarakat dan budaya Banten yang tercermin dalam Tradisi Debus dan Maulid dengan karakteristik keislaman yang kuat tanpa menjelaskan upaya mengoptimalkan kompleksitas masyarakat dan budaya tersebut (Said, 2016, hlm. 110). Karakteristik lain dari masyarakat Banten adalah kepercayaan masyarakat Banten terhadap mitos yang turut memengaruhi identitas, solidaritas, hingga status sosial masyarakat Banten (Humaeni, 2012). Karakteristik tersebut turut berpengaruh dalam sejarah masyarakat Banten.

Penelitian lain yang mengkaji tentang Sejarah Banten hanya berupaya untuk menjelaskan budaya Banten yang bertujuan untuk menanamkan dan melestarikan kearifan lokal Banten (Fauzan, 2018). Selain itu, penelitian yang menjelaskan mengenai sejarah sosial ekonomi di Banten hanya fokus pada masyarakat Baduy pasca Banten menjadi sebuah Provinsi (Bintari, 2012).
Namun demikian, upaya meninjau kembali sejarah Banten dalam rangka mengenalkan pada generasi penerus dan mengidentifikasi potensi sejarah Banten tetap dilakukan dengan mengedepankan situs Banten Girang sebagai laboratorium sejarah (Perdana, 2020).

Dalam perkembangannya, Banten sangat identik dengan unsur keislaman yang kemudian menjadi penentu sejarah Banten sekaligus menjadi kekuatan dan karakter budaya Banten (Jull, 2020). Sementara itu, penelitian yang khusus berkaitan dengan strategi dalam upaya mengoptimalkan sejarah Banten hanya membahas mengenai pengembangan museum dan situs kepurbakalaan Banten Lama dengan analisis SWOT (Hasanah, 2016). Khusus untuk strategi pada masa Sultan Ageng Tirtayasa, pembahasannya hanya mencakup strategi anti kolonialisme melalui kerja sama dengan kerajaan lain (Indriani, 2018). Sementara, strategi dalam menanggulangi kemiskinan di Banten hanya membahas konteks kekinian tanpa merunut pada konteks sejarah (Rah Adi Fahmi dkk., 2018).

Berkaca pada penelitian-penelitian sebelumnya, diperlukan tinjauan kembali terhadap sejarah Banten dengan menggunakan studi kasus pada masa Pemerintahan Sultan Ageng Tirtayasa yang penulis anggap sebagai acuan keberhasilan pengelolaan Pemerintahan yang berdampak secara signifikan pada kesejahteraan masyarakat di Banten kala itu. Berbeda dengan penelitian-penelitian sebelumnya, penulis berupaya menyibak permasalahan yang berulang terjadi di Banten, yakni konflik elite penguasa (pemerintah) yang memicu kemunduran Banten pada masa VOC hingga saat ini dan mengimplementasikan pendekatan Defense Agency, yaitu strategi dalam memahami konteks, membuat keputusan dengan mempertimbangkan risiko, dan mengeksekusi keputusan dalam keadaan sulit dalam rangka mengoptimalkan potensi-potensi yang dimiliki Banten sehingga mampu mengulang kembali keberhasilan di masa lalu. Pendekatan Defense Agency ini merupakan upaya mereduksi serangan dalam bentuk konflik antar elite penguasa (pemerintahan). Pendekatan ini pada dasarnya telah diterapkan oleh Sultan Ageng Tirtayasa sebagai seorang pemimpin dengan latar belakang militer yang dimiliki. Perbedaan lain penelitian ini dengan penelitian sebelumnya adalah penggabungan konteks 
ilmu sejarah dengan pendekatan strategi yang lazim digunakan dalam ilmu ekonomi sehingga diharapkan mampu memperkaya analisa dan hasil temuan.

\section{Metode}

Dalam penulisan ini penulis menggunakan pendekatan kualitatif dengan wawancara dan studi kepustakaan, tentunya dengan ditambah metode dalam penulisan sejarah, yaitu (1) heuristik sebagai langkah pertama dalam mengumpulkan sumber-sumber sejarah yang dapat mendukung penulisan; (2) kritik sebagai langkah penyaringan dalam menggunakan sumber penulisan sehingga kredibilitas informasi dan hasil penulisan dapat dipertanggungjawabkan; (3) interpretasi berdasarkan fakta yang didapat dari berbagai sumber; serta (4) historiografi sebagai tahap terakhir dengan menuliskan hasil interpretasi menjadi rangkaian peristiwa sejarah yang menarik. Selain itu, penulis menggunakan analisa secara deskriptif analitis yang mengacu pada sejarah serta ekonomi (berkaitan dengan strategi) untuk menemukan permasalahan dan alternatif solusi.

Penelitian ini berupaya mendeskripsikan konteks masa lalu untuk menjelaskan bagaimana kondisi yang seharusnya dan mengapa hal tersebut terjadi. Dengan menggunakan pendekatan kualitatif dan metode sejarah diharapkan dapat ditemukan permasalahan yang spesifik terkait dengan kondisi di masa lalu dan bagaimana seharusnya mengimplementasikan kondisi tersebut pada masa sekarang. Metode yang digunakan adalah metode deskriptif-analitis untuk menjelaskan fenomena yang terjadi berdasarkan analisa berupa narasi hasil heuristik, kritik, interpretasi, dan historiografi. Data yang digunakan merupakan data sekunder hasil dari wawancara dan studi kepustakaan. Sementara itu, masa pemerintahan Sultan Ageng Tirtayasa merupakan titik tolak atau acuan yang dianggap mewakili kondisi seharusnya sehingga penelitian ini menggunakan studi kasus berdasarkan aspek objek kajian. Studi kasus dipilih karena mampu menyelidiki situasi, peristiwa, dan kondisi tertentu guna memberikan pemahaman dalam proses terjadinya suatu fenomena.

Penelitian dilakukan pada tahun 2021 dengan melakukan wawancara pada peneliti sejarah Banten, dan melakukan observasi pada masyarakat di sekitar Kawasan Banten Lama dan beberapa objek peninggalan Kerajaan
Banten, serta studi kepustakaan selama 2 bulan. Data hasil wawancara dan studi kepustakaan tersebut kemudian dianalisis menggunakan metode kritik dan diinterpretasi sehingga mampu menjawab pertanyaan penelitian. Pemilihan pendekatan Defence Agency dirasa tepat guna memahami konteks sejarah Banten, mengoptimalkan potensi Banten, dan membuat kebijakan yang mampu mengembalikan kembali kejayaan Banten.

\section{Hasil dan Pembahasan}

\subsection{Keadaan Banten Tahun 1651 sampai dengan 1682}

Untuk menggambarkan keadaan Banten, terlebih dahulu digambarkan kondisi geografis Kesultanan Banten yang menaungi pelabuhan Banten pada awal abad ke 16 yang dilukiskan oleh Couto, yaitu Banten terletak di pertengahan teluk yang memiliki lebar sekitar 3 mil dan panjang sekitar 850 depa serta dari tepi laut memiliki panjang sekitar 400 depa (Wibisono, 1995, hlm. 89). Banten memiliki luas sekitar $10.000 \mathrm{~km} 2$, wilayah yang tidak lebih luas dari sebuah kabupaten yang besar di Perancis. Wilayah Banten membentang dari Tangerang sampai Tulang Bawang dan dari Pelabuhan ratu sampai Silebar dengan jumlah penduduk sekitar 80.000 sampai 100.000 orang pada penghujung abad ke16. Belanda menggambarkan bahwa Banten memiliki luas hampir sama dengan Amsterdam kuno. Selain itu, Belanda menggambarkan bahwa Banten terletak pada dataran kosong di kaki perbukitan. Untuk sampai ke Banten, diperlukan jarak tempuh sekitar 25 mil antara Jawa dan Sumatra. Pada kedua sisi kota mengalir sungai, di mana salah satu dari sungai itu mengalir melewati kota.

Saat itu, pelabuhan Banten sudah berkembang sebagai kota pelabuhan yang ramai, di mana terdapat para pedagang Cina, Arab, Portugis, dan Inggris selain dari pedagang Belanda dan pribumi. Komunikasi antara pedagang pribumi dan pedagang asing dengan menggunakan lingua franca (bahasa Melayu). Dapat dikatakan bahwa Banten merupakan salah satu pelabuhan besar di Nusantara. Dengan ditunjang oleh potensi alam berupa beras dan komoditi unggulan rempah-rempah berupa lada, Banten sangat maju dalam hal ekonomi seperti pada kota-kota dagang pada 
umumnya. Beberapa hal yang menunjang pelabuhan Banten berkembang dengan sangat pesat adalah pelabuhan Banten terletak di jalur dagang Nusantara yang merupakan bagian dari jalur dagang Asia dan dunia, dan terletak di ujung barat pulau Jawa dekat dengan selat Sunda. Tome Pires menyebutkan pelabuhan Banten merupakan bandar yang sangat penting, menjadi perhatian pelayaran dan perdagangan internasional. Dengan kata lain, pelabuhan Banten termasuk dalam jaringan jalur sutra (Silk Road). Selain itu, sumber Cina Shun Peng Hsiang Sung pada tahun 1413 pun menyebutkan adanya jalur pelayaran yang melalui pelabuhan Banten. Hal ini menandai bahwa pelabuhan Banten memang sudah berkembang sebelum Sultan Ageng Tirtayasa memimpin kesultanan Banten (Wibisono, 1995, hlm. 89).

Satu hal yang membuat pelabuhan Banten berkembang dengan sangat pesat adalah jatuhnya Malaka ke tangan VOC tahun 1646 sekaligus dikuasainya Maluku oleh VOC. Hal ini yang membuat pedagangpedagang Islam maupun pedagang India dan Cina beralih berdagang ke pelabuhan Banten. Terbukti dengan kemampuan kesultanan Banten menarik minat pedagang-pedagang dari Iran, Hindustan, Arab, Inggris, Prancis, Denmark, Pegu, Filipina, dan Cina untuk berdagang di pelabuhan Banten yang tercatat dalam catatan harian Belanda.

Sebagai sebuah pelabuhan, perkembangan pelabuhan Banten ditunjang oleh keadaan ekologi dan iklim yang bersahabat. Pelabuhan yang baik adalah pelabuhan yang aman, terlindung dari angin maupun arus yang kuat. Pelabuhan Banten terletak dalam sebuah teluk yang terlindung sehingga membantu para pedagang yang akan merapatkan kapalnya ke pelabuhan. Dalam pelabuhan tersebut terdapat seorang Syahbandar yang membantu para pedagang dalam berdagang. Syahbandar sendiri memiliki spesialisasi khusus dalam hal melayani pedagang. Bagi pedagang-pedagang dari Nusantara akan ditangani oleh Syahbandar yang berbeda dengan Syahbandar yang menangani pedagang asing. Selain sebagai perantara dalam perdagangan, Syahbandar ini yang memungut pajak dan bea cukai untuk kemudian diserahkan kepada mangkubumi yang diteruskan pada pihak kerajaan.
Dalam perdagangan sendiri, dikenal sistem commenda, sebuah sistem penanaman modal yang nantinya keuntungan akan dibagi antara pemilik modal dengan pemilik kapal. Dalam hal kapal, tidak diketahui secara pasti bagaimana bentuk kapal yang dimiliki oleh kesultanan Banten, namun Willem Lodwycksz yang mengikuti ekspedisi Belanda di bawah pimpinan Cornelis de Houtman menyebutkan bahwa kapal perang yang dimiliki oleh kesultanan Banten menyerupai kapal galai dengan dua tiang layar yang dilengkapi dengan sebuah serambi yang sempit. Kesultanan Banten sendiri merupakan penghasil lada dan beras. Lada dan beras secara bergantian ditanam. Untuk lada, Sultan Ageng Tirtayasa menaruh perhatian lebih karena Banten merupakan penghasil lada terbesar di bagian barat Pulau Jawa. Inilah yang memicu VOC semakin berniat menguasai Banten.

\subsection{Tekanan terhadap Banten}

Sultan Ageng Tirtayasa selama memerintah kesultanan Banten sangat menentang segala bentuk penjajahan asing atas daerah kekuasaannya, termasuk kehadiran VOC yang hendak menguasai Banten sangat ditentang oleh Sultan Ageng Tirtayasa. Oleh sebab itu, VOC yang berusaha melakukan blokade terhadap pelabuhan Banten dengan menyerang kapal-kapal yang hendak berdagang di Banten mendapatkan perlawanan dari pasukan Banten. Perlawanan itu awalnya diwujudkan dengan perusakan terhadap segala instalasi milik VOC di wilayah kekuasaan kesultanan Banten. Dengan tindakan perlawanan demikian, Sultan Ageng Tirtayasa mengharapkan agar VOC segera meninggalkan Banten. Tangerang dan Angke dijadikan sebagai garis terdepan pertahanan dalam menghadapi VOC. Pasukan Banten menyerang Batavia pada 1652 juga dimulai dari Tangerang dan Angke.

Saat perlawanan sering terjadi, Sultan Ageng Tirtayasa sering kali mengadakan hubungan kerja sama dengan kesultanan lain, seperti kesultanan Cirebon dan Mataram serta dengan Turki, Inggris, Perancis, dan Denmark (Michrob, 1993, hlm. 135). Hal ini dilakukan agar Banten dapat memperkuat kedudukan dan kekuatannya dalam menghadapi kekuatan VOC. Dari Turki, Inggris, Perancis, dan Denmark inilah Banten mendapatkan banyak bantuan berupa senjata api. Sultan Ageng Tirtayasa pun melakukan penyatuan terhadap 
daerah yang dikuasai oleh kesultanan Banten, yaitu Lampung, Bangka, Silebar, Indragiri dalam kesatuan pasukan Surosowan (Michrob, 1993, hlm. 136). Menghadapi kenyataan tersebut, VOC pun melakukan penyatuan kekuatan dengan menyewa serdadu-serdadu dari Kalasi, Ternate, Bandan, Kejawan, Bali, Makasar, dan Bugis karena serdadu Belanda jumlahnya sedikit. Pada saat terjadi perlawanan, serdadu-serdadu pribumi inilah yang melawan pasukan Banten, sedangkan serdadu Belanda lebih banyak berada di belakang serdadu pribumi tersebut (Michrob, 1993, hlm. 136). Semakin kuatnya pasukan Banten, ditambah dengan kurangnya persiapan VOC dalam menghadap Banten karena sedang berperang dengan Makasar membuat VOC pada sekitar bulan November dan Desember 1657 mengajukan penawaran gencatan senjata (Michrob, 1993, hlm. 137). Pertempuran antara Banten dan VOC ini sangat merugikan kedua belah pihak. Gencatan senjata pun baru dapat dilakukan setelah utusan VOC dari Batavia mendatangi Sultan Ageng Tirtayasa pada tanggal 29 April 1658 dengan membawa rancangan perjanjian yang berisi sepuluh pasal. Di antara pasal tersebut, Sultan Ageng Tirtayasa mengajukan dua pasal perubahan. Namun, hal tersebut ditolak oleh VOC sehingga perlawanan dan peperangan kembali terjadi.

Penolakan dari VOC tersebut semakin menguatkan keyakinan Sultan Ageng Tirtayasa bahwa tidak akan ada kesesuaian pendapat antara kesultanan Banten dengan VOC sehingga jalan satu-satunya adalah dengan kekerasan, yaitu berperang. Oleh sebab itu, Sultan Ageng Tirtayasa mengumumkan perang sabil dengan terlebih dahulu mengirimkan surat ke VOC pada tanggal $11 \mathrm{Mei}$ 1658. Pertempuran antara VOC dengan pasukan Banten berlangsung secara terus menerus mulai dari bulan Mei 1658 sampai dengan tanggal 10 Juli 1659 (Djajadiningrat, 1983, hlm. 71). Penyerangan yang dilakukan Banten secara terus menerus terhadap VOC membuat kedudukan VOC semakin terdesak sampai mendekati batas kota Batavia. Akhirnya VOC mengajukan gencatan senjata. Menyadari bahwa Banten akan menolak perjanjian gencatan senjata, maka VOC membujuk sultan Jambi untuk mengakomodasi perjanjian tersebut. Maka sultan Jambi pun mengirimkan utusannya yaitu Kiyai Damang Dirade Wangsa dan Kiyai Ingali Marta Sidana. Pada tanggal 10 Juli 1659 , ditandatangani perjanjian gencatan senjata antara Banten dan VOC (Michrob, 1993, hlm. 147). Gencatan senjata ini dimanfaatkan oleh Sultan Ageng Tirtayasa untuk melakukan konsolidasi kekuatan, di antaranya menjalin hubungan dengan Inggris, Perancis, Turki, dan Denmark dengan tujuan memperoleh bantuan senjata. Gencatan senjata ini membuat blokade yang dilakukan oleh VOC terhadap pelabuhan Banten kembali dibuka. Berbagai cara yang dilakukan oleh Sultan Ageng Tirtayasa membuat Banten berkembang dengan pesat. Hal tersebut memicu Gubernur Jendral Ryklop van Goens sebagai pengganti Gubernur Jendral Joan Maetsuyker menulis surat yang ditujukan kepada kerajaan Belanda tertanggal 31 Januari 1679 tentang usaha untuk menghancurkan dan melenyapkan Banten (Tjandrasasmita, 1967, hlm. 35).

Setelah perjanjian gencatan senjata, VOC menggunakan kesempatan tersebut untuk mempersulit kedudukan Banten. Cara yang dilakukan adalah dengan mengadakan kerja sama dengan kesultanan Cirebon dan kesultanan Mataram. Puncaknya adalah ketika Amangkurat II menandatangani perjanjian dengan VOC. Selain itu, Cirebon pun berada di bawah kekuasaan VOC pada tahun 1681. Dengan Mataram dan Cirebon di bawah kendali VOC, maka posisi Banten semakin terjepit karena Mataram dan Cirebon merupakan kesultanan yang memiliki hubungan baik dengan Banten. Posisi tersebut makin sulit dengan terjadinya perpecahan di dalam kesultanan Banten sendiri. Putra Sultan Ageng Tirtayasa, yaitu Pangeran Gusti dan Pangeran Arya Purbaya mendapatkan kekuasaan, masing-masing untuk mengurusi kedaulatan ke dalam kesultanan. Sementara kedaulatan keluar kesultanan masih dikendalikan oleh Sultan Ageng Tirtayasa. Pemisahan kekuasaan ini diketahui oleh wakil Belanda di Banten, yaitu W. Caeff yang kemudian mendekati dan menghasut Pangeran Gusti untuk mencurigai ayahnya dan saudaranya sendiri.

Setelah itu, pemberontakan terus terjadi meskipun VOC telah beberapa kali meminta Sultan Ageng Tirtayasa untuk menyerah. Untuk menyelesaikan perlawanan tersebut, Sultan Haji mengutus 52 orang keluarganya untuk membujuk Sultan Ageng Tirtayasa. Setelah berhasil dibujuk, Sultan Haji dan VOC menerapkan tipu muslihat dengan mengepung iringiringan Sultan Ageng Tirtayasa menuju ke istana 
Surosowan pada tanggal 14 Maret 1683. Sultan Ageng Tirtayasa berhasil ditangkap, namun Pangeran Arya Purbaya berhasil lolos. Kemudian Sultan Ageng Tirtayasa dipenjarakan di Batavia sampai meninggal pada tahun 1692. Sultan Haji sendiri akhirnya naik takhta dengan restu VOC, memerintah dari tahun 1682 sampai dengan 1687. Pada tanggal 17 April 1684, ditandatanganilah perjanjian dalam bahasa Belanda, Jawa, dan Melayu yang berisi 10 pasal. Perjanjian inilah yang menandai berakhirnya kekuasaan kesultanan Banten, dan dimulainya monopoli VOC atas Banten. Dengan demikian berakhirlah perlawanan Sultan Ageng Tirtayasa setelah dikhianati oleh anaknya sendiri.

Lebih dari tiga abad pasca konflik elite penguasa yang terjadi di Kerajaan Banten, konflik elite penguasa ini nyatanya terus terjadi pada proses pembentukan Provinsi Banten yang terpisah dari Provinsi Jawa Barat. Konflik tersebut disebabkan oleh faktor sejarah, faktor ekonomi, dan juga faktor politik (Rohmah, 2018). Nyatanya, tarik menarik pengaruh politik yang disebabkan oleh penguasaan terhadap faktor-faktor ekonomi masih terjadi. Hal ini yang menurut penulis menjadi penyebab Banten mengalami stagnansi dalam hal kesejahteraan sehingga angka kemiskinan tinggi dan cenderung meningkat pada tahun lalu yang diperparah dengan dampak Pandemi Covid-19.

\subsection{Implementasi Strategi Sultan Ageng Tirtayasa}

Defence Agency merupakan sebuah pendekatan strategi yang digunakan untuk menyelesaikan permasalahan dalam keadaan yang tidak menentu dengan menggunakan tiga langkah, yaitu memahami konteks, membuat keputusan dengan mempertimbangkan risiko, dan mengeksekusi dalam keadaan yang tidak menentu. Defence Agency mengacu pada penelitian Bryan dkk. (2010) berjudul A Dynamic Strategy for Uncertain Times. Ketiga langkah tersebut merupakan satu kesatuan yang saling berhubungan, tidak terpisahkan, dan dapat dijadikan sebagai acuan dalam pengambilan keputusan. Untuk memahami konteks, membuat keputusan, dan melakukan eksekusi diperlukan observasi, orientasi, serta informasi.

Langkah pertama dalam Defence Agency adalah memahami konteks yang dilakukan dengan cara mencari informasi penting sekaligus melakukan penilaian untuk mendapatkan gambaran mengenai situasi dan kondisi secara menyeluruh. Dalam hal ini, penulis membagi menjadi dua, yaitu melakukan penilaian terhadap lingkungan eksternal dengan tidak mengabaikan aspek demografi, ekonomi, dan teknologi serta melakukan penilaian terhadap lingkungan internal. Selain itu, hal lain yang harus dipertimbangkan adalah tren global, dan iklim bisnis, termasuk di dalamnya struktur kompetensi serta perspektif stakeholder. Dalam memahami konteks, sangat perlu untuk melakukan penilaian terhadap lingkungan internal yang terdiri dari upaya mempertahankan kultur internal organisasi, mempertahankan performa yang baik, dan mengidentifikasi adanya gap dalam performa secara keseluruhan. Oleh sebab itu, dalam memahami lingkungan eksternal dan internal diperlukan adanya asumsi untuk mendesain keputusan yang dapat digunakan secara jangka panjang.

Jika langkah dalam memahami konteks tersebut dikaitkan dengan Banten pada masa Pemerintahan Sultan Ageng Tirtayasa, kemampuan Sultan Ageng Tirtayasa dalam memahami konteks sangat mumpuni. Sultan Ageng Tirtayasa mampu melakukan penilaian terhadap lingkungan eksternal dengan mempertimbangkan peta persaingan antara pedagang yang melakukan kegiatan bisnis di Pelabuhan Banten. Pedagang yang dianggap potensial dan tidak melakukan intervensi berlebihan diizinkan untuk berdagang, seperti pedagang Cina dan Gujarat, sementara pedagang Portugis, Inggris dan Belanda dibatasi bahkan cenderung ditutup aksesnya agar tidak mengganggu iklim bisnis dan proses ekonomi yang diciptakan oleh Kerajaan Banten. Guna menjamin proses perdagangan, Kerajaan Banten juga mengadakan perjanjian kerja sama baik dengan sesama kerajaan di Nusantara atau dengan pedagang asing serta melengkapi pertahanan dengan kekuatan militer yang mumpuni.

Sementara pemahaman konteks internal diwujudkan dengan memahami potensi alam yang dimiliki, yakni sebagai penghasil beras dan lada terbesar serta memiliki letak geografis strategis. Pemahaman terhadap potensi tersebut diwujudkan dengan optimalisasi hasil alam untuk kesejahteraan masyarakat. Guna menunjang hal tersebut, heterogenitas yang terjadi di masyarakat diatur 
sedemikian rupa sehingga tidak menimbulkan ketimpangan dengan basis hukum Islam yang mengacu pada Al Quran dan Al Hadist. Elit Penguasa, Ulama, Jawara, dan Rakyat Jelata dipersatukan sebagaimana yang tercantum dalam hukum Islam. Pemahaman konteks internal dan eksternal tersebut membuat Sultan Ageng Tirtayasa mampu mengelola Pemerintahan Kerajaan, menghindari konflik dengan sekaligus mengatur bisnis di Pelabuhan Banten hingga 31 tahun. Pola pemahaman terhadap konteks masih sangat relevan untuk diterapkan pada masa sekarang.

Pemahaman terhadap konteks internal dan eksternal tersebut sangat diperlukan dalam mengulang kembali kesuksesan Kerajaan Banten pada masa kini, setidaknya dalam mengatasi Pandemi Covid-19 yang saat ini tengah melanda Banten. Potensi pertanian terutama beras dan lada selain peternakan dan perikanan perlu kembali dioptimalkan guna mencapai ketahanan pangan. Selain itu ketersediaan energi minyak dan industri baja yang berada di Banten seharusnya mampu dipahami oleh Pemerintah Provinsi Banten sehingga mampu dioptimalkan untuk pendapatan daerah yang berkontribusi pada kesejahteraan masyarakat.

Langkah selanjutnya dalam Defence Agency adalah membuat keputusan dengan mempertimbangkan risiko. Dalam hal ini diperlukan visi dan tujuan yang hendak dicapai. Kriteria visi tersebut setidaknya dapat dipahami dengan mudah dan tidak sulit untuk diaplikasikan. Selain menetapkan visi dan tujuan, hal lain yang penting dalam membuat keputusan adalah mengembangkan dan memprioritaskan inisiatif. Langkah yang dapat dilakukan adalah membuat skenario dengan mengeksplorasi kemungkinan terburuk yang akan dihadapi apabila menerapkan skenario tersebut. Selain itu, langkah yang dapat dilakukan adalah mengidentifikasi gap menuju tujuan dan meminimalisir risiko dengan mengembangkan inisiatif. Alat untuk mengembangkan inisiatif ini terdiri dari strategic playbook untuk mengetahui nilai dari inisiatif dan portfolio of initiative untuk mengeksplorasi risiko yang dihadapi.

Kemampuan membuat keputusan pada masa yang sulit dilakukan oleh Sultan Ageng Tirtayasa kala VOC melakukan blokade terhadap Pelabuhan Banten. Inisiatif yang diambil oleh Sultan Ageng Tirtayasa saat itu adalah dengan melakukan perlawanan guna menembus blokade tersebut. Selain melakukan inisiatif penyerangan terhadap kapal-kapal VOC, Sultan Ageng Tirtayasa juga melakukan perjanjian kerja sama dengan pihak asing, salah satunya dengan kongsi dagang Inggris (EIC) sebagai wujud antisipasi terhadap serangan balik dari VOC. Inisiatif dan langkah antisipatif tersebut mencerminkan visi dan misi yang jelas dari Sultan Ageng Tirtayasa serta dapat diimplementasikan pada masa sekarang.

Menghadapi Pandemi Covid-19 yang tengah melanda wilayah Banten, Pemerintah Provinsi Banten perlu untuk melakukan berbagai inisiatif terutama dalam menjamin ketersediaan pangan dan obat-obatan serta mengantisipasi dampak Pandemi Covid-19, seperti meningkatnya angka kemiskinan yang telah tergambar pada tahun 2020. Optimalisasi Anggaran Pendapatan dan Belanja Daerah (APBD) untuk memberikan insentif bagi masyarakat yang terdampak Pandemi Covid-19 merupakan salah satu inisiatif sekaligus langkah antisipatif dalam kondisi yang sulit.

Langkah terakhir adalah mengeksekusi dalam situasi yang tidak menentu. Untuk dapat melakukan hal tersebut, diperlukan beberapa proses, di antaranya adalah iterative management cycle, yaitu menempatkan sumber daya secara tepat, Performance Management System yang akuntabilitas, dan mengolaborasikan kepemimpinan hingga tingkatan terendah. Keseluruhan hal tersebut saling berhubungan dan tidak dapat dipisahkan antara satu dengan yang lainnya. Selain itu, penerapannya harus dilakukan secara berkesinambungan setahap demi setahap agar mencapai kesuksesan dalam menghadapi kondisi yang tidak menentu.

Berkaitan dengan eksekusi, Sultan Ageng Tirtayasa telah melakukan langkah-langkah yang tepat, termasuk mengimplementasikan hukum Islam dalam proses bisnis kerajaan hingga mengeksekusi keputusan untuk berperang menghadapi VOC yang membuat VOC mengalami kesulitan. Kepemimpinan Sultan Ageng Tirtayasa yang kuat, ditunjang kemampuan memahami konteks internal dan eksternal serta visi yang mumpuni membuat Kerajaan Banten mencapai puncak kejayaannya. Hanya saja konflik elite penguasa terutama 
dengan anaknya sendiri tidak mampu ditangani sehingga memicu kemunduran bagi Kerajaan Banten.

Berkaca pada Kerajaan Banten pada masa Pemerintahan Sultan Ageng Tirtayasa, pemahaman konteks yang baik, kemampuan membuat keputusan, dan eksekusi akan melahirkan efektivitas kebijakan yang tercermin dengan adanya kredibilitas, kepastian, dan kepatuhan sehingga bermuara pada penguatan dan kesejahteraan masyarakat. Namun demikian, tetap diperlukan kesadaran bersama dari para elite penguasa (pemerintah) untuk meminimalisir konflik sehingga tidak menghambat alokasi, distribusi, dan stabilisasi kebijakan.

\section{Kesimpulan}

Banten mengalami kemunduran yang ditandai dengan meningkatnya jumlah kemiskinan, terutama pada masa Pandemi Covid-19. Padahal Banten pernah mengalami masa kejayaan pada masa pemerintahan Sultan Ageng Tirtayasa. Meskipun mengalami kejayaan, namun Banten juga mengalami tekanan blokade ekonomi oleh VOC dan konflik politik. Dalam merespons tekanan tersebut, Sultan Ageng Tirtayasa menggunakan kemampuannya untuk memahami konteks, membuat keputusan dengan mempertimbangkan risiko, dan mengeksekusi keputusan dalam keadaan sulit. Implementasi yang disebut sebagai Defence Agency tersebut mampu membawa Banten pada masa kejayaan.

Dengan berpatokan pada kesuksesan kepemimpinan Sultan Ageng Tirtayasa selama 31 tahun, saat ini Banten berusia 21 pasca menjadi sebuah Provinsi pada tahun 2000 sehingga terbuka harapan setidaknya 10 tahun bagi Banten untuk mengejar ketertinggalan dan mengoptimalkan potensi yang dimiliki guna meningkatkan kesejahteraan penduduk serta mengulang kembali kejayaan masa lalu pada tahun 2031 dengan catatan mampu menerapkan Defence, Agency dengan baik.

\section{Ucapan Terima Kasih}

Penulisan jurnal berjudul Meninjau Kembali Sejarah Banten: Study Kasus Pemerintahan Sultan Ageng Tirtayasa dan Implementasi Kepemimpinannya tidak akan dapat diselesaikan tanpa bantuan berbagai pihak. Oleh sebab itu, penulis mengucapkan terima kasih kepada Tuhan Yang Maha Esa atas kemampuan yang telah diberikan; orang tua dan keluarga penulis yang telah memberikan dukungan; Deputi Bidang Koordinasi Revolusi Mental, Pemajuan Kebudayaan, dan Prestasi Olahraga serta Asisten Deputi Pemajuan dan Pelestarian Kebudayaan, Kemenko PMK yang telah memberikan motivasi dan kesempatan untuk menyelesaikan jurnal ini. Selain itu, penulis juga mengucapkan terima kasih kepada Biro Hukum, Persidangan, Informasi, dan Komunikasi, Biro Perencanaan dan Kerjasama, Perpustakaan Universitas Indonesia dan segenap civitas akademika Universitas Indonesia, serta seluruh pihak yang sudah terlibat dalam penyusunan jurnal ini.

\section{Referensi}

Anggraheni, D. S., Attamimi, H., \& Jumardi. (2020). Perkembangan Kerajaan Islam di Banten pada Masa Sultan Ageng Tirtayasa dalam Aspek Politik dan Sosial. Pattingalloang: Jurnal Pemikiran Pendidikan dan Penelitian Kesejarahan, 7(2), 146-159. https://ojs.unm.ac.id/ pattingalloang/article/view/13518

Bryan, L., Elder, R., O'Brien, B., \& Rutherford, S. (2010). A dynamic strategy for uncertain times. In McKinsey on Government.

Fauzan, R. (2018). Implementasi Materi Sejarah Lokal Gerakan Sosial Messianistik dan Nativisme di Banten melalui Pendekatan Saintifik dalam Kurikulum Nasional. Historia: Jurnal Pendidik dan Peneliti Sejarah, 1(2), 25-34. https://doi.org/10.17509/historia.v1i2.10903

Fida, H. A. (2019). Sejarah Banten dalam Perspektif Halwany Michrob (Studi Cacatan Masa Lalu Banten) [UIN Sultan Maulana Hasanuddin Banten]. http://repository.uinbanten.ac.id/id/eprint/3642

Guillot, C. (2008). Banten: Sejarah dan Peradaban Abad X-XVII (D. Perret (ed.); H. Setiawan (penerj.)). Kepustakaan Populer Gramedia.

Guillot, K. C. (2009). Membaca Sejarah Banten dari Sumber Asing. Jurnal Lektur Keagamaan, 7(2), 313-330.

Humaeni, A. (2012). Makna Kultural Mitos dalam Budaya Masyarakat Banten. Antropologi Indonesia, 33(3), 159-179. https://doi.org/ 10.7454/ai.v33i3.2461

Octavian, A., \& Yulianto, B. A. (2014). Degradasi Kebudayaan Maritim: Sejarah, Identitas, dan Praktik Sosial Melaut di Banten. Masyarakat Indonesia, 40(2), 159-176. https://doi.org/10.14203/jmi.v40i2.115

Perdana, N. G. (2020). Mendobrak Dominasi Perkembangan Sejarah: Praktik Pengenalan Kembali Sejarah Pra-Islam dan Tinggalannya di Banten. Umbara: Indonesian Journal of Anthropology, 5(2), 76-89. https://doi.org/10.24198/umbara.v5i2.25504

Rah Adi Fahmi, G., Setyadi, S., \& Suiro, U. (2018). Analisis Strategi Penanggulangan Kemiskinan di Provinsi Banten. Jurnal Ekonomi-Qu, 8(2), 227-248. https://doi.org/10.35448/jequ.v8i2.4450

Rohmah, N. S. (2018). Elit dan Pemekaran Daerah; Konflik Antar Elit dalam Proses Pembentukan Provinsi Banten. Cosmogov: Jurnal IImu Pemerintahan, 4(1), 90-105. https://doi.org/10.24198/ cosmogov.v4i1.15925

Said, H. A. (2016). Islam dan Budaya di Banten: Menelisik Tradisi Debus dan Maulid. Kalam, 10(1), 109-138. https://doi.org/10.24042/ $\mathrm{klm} . \mathrm{v} 10 \mathrm{i} 1.338$

Ulfah, S. M. (2020). Perlawanan Banten terhadap Belanda (Awal Banten Berdiri, Silsilah Pemimpin dan Kehidupan Politiknya, Masa Kejayaan, Perkembangan Ekonomi dan Sosial Budaya, Runtuhnya Kerajaan, dan Peninggalan Arkeologis). https://doi.org/10.31219/osf.io/ux9b7

Wibisono, S. C. (1995). Kegiatan Perdagangan di Bandar Banten dalam Lalu Lintas Perdagangan Jalur Sutra. In Banten Kota Pelabuhan Jalan Sutra (Kumpulan Makalah Diskusi). Departemen Pendidikan dan Kebudayaan. 